\title{
The Regional Uneven Development and the State Intervention to Reshape the Spatial Hierarchy
}

\author{
Sangwan Lee (Corresponding Author) \\ Nohad A. Toulan School of Urban Studies \& Planning \\ Portland State University \\ 506 SW Mill Street, Portland, Oregon, 97201 \\ Email: sangwan@pdx.edu \\ YunJae Ock \\ Nohad A. Toulan School of Urban Studies \& Planning \\ Portland State University \\ 506 SW Mill Street, Portland, Oregon, 97201
}

\begin{abstract}
Mina Kim
Nohad A. Toulan School of Urban Studies \& Planning Portland State University

506 SW Mill Street, Portland, Oregon, 97201
\end{abstract}

Greg Schrock, Ph.D.

Nohad A. Toulan School of Urban Studies \& Planning

Portland State University

506 SW Mill Street, Portland, Oregon, 97201

Received: January 21, 2021

Accepted: March 2, 2020

Published: July 16, 2021

doi:10.5296/ijrd.v8i2.18231

URL: http://dx.doi.org/10.5296/ijrd.v8i1.18231 


\section{Abstract}

The central question in this study concerns the way in which the state intervention is strong enough to reverse the tide of regional uneven development that has been intentionally created by the state. To answer the question, we conduct a case study of the Innovation Cities in South Korea. We use the K-means Cluster Analysis and a Two-way Analysis of Variance with well-defined three indices on regional economic competitiveness. The results reveal that the development of Innovation Cities does not have a desirable impact on converging the regional disparity between core and periphery regions. At best, the regional gap has not widened. The outcomes also imply that the trickle-down effects have not been observed during the time-period of study. The findings suggest that policymakers carefully consider diverse full-factors toward periphery regions with consideration of the regional heterogeneity rather than focusing on the homogeneous approach.

Keywords: Regional Uneven Development, State Intervention, Innovation Cities, Regional Economic Competitiveness

\section{Introduction}

Decades of research on regional economic development have demonstrated that, in many cases, the cumulative acquisition or deprivation of regional wealth, power, and capabilities has led to regional uneven development over a long period (Cojanu, 2008). The uneven development has increasingly become a problematic issue globally due to its potential adverse effects on individuals, communities, regions, and, more broadly, countries. Accordingly, there have been diverse state efforts in many countries, including South Korea, to mitigate the uneven development practices, such as transportation network improvement.

Since the 1970s, South Korea has been dedicated to mitigating regional polarization deliberately formed by the developmental state (Seo, 2009). However, given the limitation of the efforts and persistent uneven development practices, Roh $\mathrm{Mu}-\mathrm{Hyun}$ administration introduced the Innovation Cities in 2003. The administration intended to employ the growth center-oriented approaches; that is, the Innovation Cities can create innovation clusters in underdeveloped provinces (periphery regions) with interactive cooperation between firms, educational institutions, and research centers, and then the clusters are expected to have a positive spillover effect on the periphery regions (Seo, 2009).

In this context, this paper attempts to explore whether the development of Innovation Cities has been effective to distribute economic capabilities toward periphery regions and improve their regional competitiveness. We use the K-means Cluster Analysis and a Two-way Analysis of Variance with three indices developed by the Korea Institute for Industrial Economics and Trade (KIET), including the Regional Creativity Potential Index, the Regional Innovation Index, and the Regional Development Index. This paper contributes to existing knowledge by presenting an interesting case study that show the effectiveness of the large new town development project to develop self-sufficient localization with regional economic competitiveness in periphery regions and reverse a self-reinforcing feedback structure through the state intervention. 


\section{Uneven Development and Government Intervention}

\subsection{Theories on Uneven Development}

The existence of the power dynamics that create regional uneven development has long been acknowledged. Perroux (1950a, 1950b) develops the growth pole theory to explain the asymmetrical power and experience between actors (Meardon, 2001). The dominant actors can function as propulsive industries and exert growth impulse, which, in turn, constitutes growth poles in the economic space. Friedmann (1969) also recognizes the uneven distribution of territorial power between core and periphery regions. Cumulative causation theory (Myrdal, 1957) further observes the "vicious cycle," which suggests that the circular causation perpetuates an uncontrollable tendency leading to either cumulative economic advantages or disadvantages of regions (Cojanu, 2008). Furthermore, Krugman (1999) identifies a tug of war between centripetal forces (e.g., the classic Marshallian sources of external economies) and centrifugal forces (e.g., external diseconomies) to explain the dynamic process of the uneven development. Few core regions have a considerable centripetal force that can disproportionately concentrate economic and political power in the regions (Krugman, 1992). In addition, the theories of the Marxian school claims that the innate nature of capitalism produces and reinforces the structural inequalities and uneven development practices (Smith, 2010; Rubara, 2014).

\subsection{Negative Externalities of Uneven Development}

Due to the uneven development, diverse forms of negative externalities have been detected at diverse scales of areas, such as community and region. For instance, few core regions have the power to limit and control the economic growth and development of periphery regions, milk the resources that can lead to their growth, and create tensions between regions (Friedmann, 1969). At the community level, the demise of certain communities within the periphery regions has been observed due to the out-migration of population and industry, disinvestment, and the influx of marginalized households. The uneven development is also intertwined with other negative externalities, such as urban environmental issue that is explained in the urban political ecology theory (Swyngedouw \& Heynen, 2003). Specifically, the environmental burdens have a disproportionate impact on the lives of the marginalized population at the urban periphery with the concentration of manufacturing industry and weak environmental protection.

\subsection{Two Perspectives to Mitigate Uneven Development}

Previous academic disciplines on understanding and responding to the uneven development has primarily categorized into two conflicting viewpoints: (1) neoliberal and (2) Keynesian perspectives (Amin, 1999). First, the unbalanced growth theory describes geographical growth centers and argues that polarization is inevitable during the beginning phases of economic growth in the short-term, but the "trickle-down effects" begin to equalize regional differences (Hirschman, 1958). Specifically, regional income inequality is inevitable in that core regions can generate an increasing return to scale in the earlier phase of economic growth (Williamson, 1965). However, with consideration of Kuznet's inverted-U hypothesis, 
the dominant economic resources and capabilities eventually move to more backward and periphery regions. From the neoliberal perspective, the government intervention is unnecessary to recover spatial hierarchy, as diffusion of economic capabilities and resources to periphery regions can be observed due to the negative externalities of excessive concentration in few core regions in the latter stage of economic development (Friedmann \& Weaver, 1979).

Fan and Casetti (1994), however, state that the underlying neoclassical logic may not explain the recent intensified regional polarization. They present three phases of regional dynamics: (1) regional polarization, (2) polarization reversal led to regional convergence, and (3) the recent increase in regional inequality due to the spatial restructuring of the global market and re-growth of traditional core regions. Friedmann (1969) also observes that as economic phases move from a pre-industrial phase to a fully industrialized economy, the investments tend to be more concentrated in few core regions. In path dependence theory, Martin and Sunley (2006) imply that the uneven development can be perpetual; specifically, while a few core regions can enjoy a development path with sequential phases of positive 'lock-in,' pre-existing uneven development practices are maintained. That is, since the vicious cycle continuously reinforces the impoverishment of the periphery regions (Myrdal, 1957), government interventions are needed to counteract the dynamics behind the regional inequalities.

\subsection{Empirical Studies on the Effectiveness of Government Intervention}

The government intervention tends to consist of two main approaches: (1) 'soft' policies such as investment in human capital, education, and local financial support, and (2) 'hard' policies such as improvement of physical facilities and infrastructures (Ahn et al., 2003). A body of research has examined whether both soft and hard policies are effective for the economic development in periphery regions (Barzotto et al., 2019; Camagni, 1995; Frenkel, 2000; Halvorson, 2016; Isaksen \& Trippl, 2017; Nemethova et al., 2019; Rodríguez-Pose, 2001; Tondl, 1998; Wei, 2002; Ahn et al., 2003).

While research efforts have been dedicated, generalizing findings of previous studies is difficult due to the inherent differences between studies, such as the context of the study area and types of public policies. On the one hand, Wei (2002) finds that given that the inverted-U pattern has not been observed for decades in China, the central government implemented public policies for regional economic development in periphery regions, such as improving human capital, infrastructure, and raw materials. Despite the state intervention, regional inequality has persisted because the efforts have not considered complex mechanisms, including marketization and globalization. Martin (1998) suggests that the improvement of inter-regional transport networks can strengthen core regions rather than periphery regions. The improved transportation networks enable firms in the core regions to reduce transport costs and then operate with increasing returns. On the other hand, a study conducted by Rodriguez-Pose (2001) reveals that the R\&D investment in periphery regions of Western Europe has led to not only increased R\&D expenditures but also a higher rate of economic growth in periphery regions. Zheng and Kahn (2013) find that since high-speed rail can have 
redistributed effect, businesses and households relocate to periphery regions involved in the transit network. The analysis of new industries' emergence and evolution indicates that the inflow of new knowledge from state interventions, including institution building and attraction of non-local firms and consumers, can create new industrial development paths in periphery regions (Isaksen \& Trippl, 2017).

However, few studies have examined the effectiveness of the new town development in periphery regions on improving regional economic competitiveness and mitigating regional uneven development. Even fewer empirical evidence has employed well-defined indices developed with diverse aspects of regional economic factors. In this context, we attempt to investigate whether the new town development is effective to reconstruct regional economic hierarchies by using well-developed indices that represent regional economic competitiveness.

\section{The Backgrounds on Study Area (South Korea)}

\subsection{The Developmental State and Uneven Development}

During the early stage of regional economic growth, South Korea achieved remarkable economic growth with rapid industrialization (Bae, 2003). One explanation for the rapid economic growth is state-led economic policies, which is called the developmental state (Amsden, 1992; Radice, 2008). The high degree of state intervention of the developmental state led to a high rate of economic growth through deliberate concentration on a few regions (Choi, 2007; Radice, 2008). With strategic guidance and plans, economic resources and capabilities were highly concentrated on few regions, particularly Seoul. Meanwhile, the distributional realm was withdrawn due to the adherence to the achievement of economic growth and the improvement of economic competitiveness at the expense of other objectives (Onis et al., 1991). As a result, the developmental state policies led to two consequences in South Korea: (1) dynamic economic activities and rapid economic growth at few core regions and (2) a vicious cycle of deepening the regional disparity at periphery regions (S. T. Kim et al., 1991).

From the territorial political perspective, Park (2008) argues that the spatial selectivity inherent in the developmental state's industrial and regional policies has created regional favoritism and increasing economic disparity between regions. The regional gap has led to political tensions with the spatial, scalar, or territorial relations, which stimulated the scalar restructuring of the state.

\subsection{The Decentralized Efforts}

Due to the democratic movement, the rise of middle-class population, the growing power of the private corporation, and, more importantly, the liberalization of the market, the degree of the developmental state in South Korea declined since the 1980s (Minns, 2001; Onis et al., 1991). Nonetheless, the characteristics of the developmental state remain in South Korea, while the state has been taking efforts to mitigate deliberately formed regional polarization. In other words, the highly centralized authorities have attempted to overcome the negative outcomes through the decentralization of regional economic capabilities with state 
intervention (S. E. Kim, 2014).

For instance, since the 1970s, the Comprehensive National Land Development Plans placed emphasis on directing the regional economic development opportunities, capabilities, and productivity toward the growth poles and a few other special areas in periphery regions. The Park Jung-Hee administration in the 1970s invested in the improvement of a well-endowed built environment to concentrate on manufacturing and export activities into periphery regions. During the 1980s, the selected 15 regional growth centers and 28 integrated regional settlement areas were developed to distribute economic growth capabilities throughout the country. In 1990s, tax exemptions were offered to firms that relocate from the core region to periphery regions.

However, descriptive statistics in Figure 1 reveals the persistent regional gap between 1970 and 2000. It suggests that the government-led efforts for decades were not effective to attain their goals. Also, unlike the inverted-U hypothesis suggests, the trickle-down effects that mean a diffusion of economic capabilities and resources to periphery regions has not been observed.

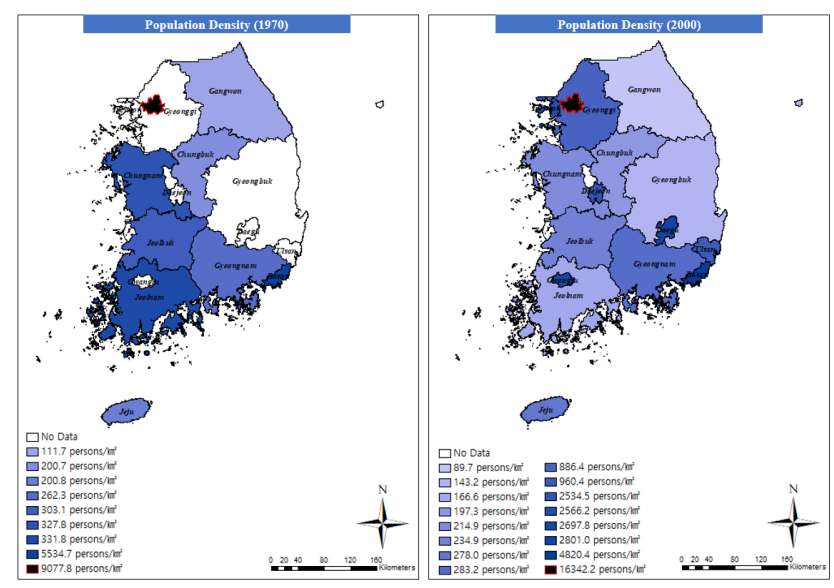

Figure 1. The Population Density at the Regional Level in 1970 and 2000

Source: Statistics Korea.

\subsection{Innovation Cities}

With consideration of the limitations of the previous efforts and persistent uneven development practices, Roh Mu-Hyun administration in 2003 developed a policy framework, Innovation Cities, to achieve balanced regional economic development via the decentralization of administration power, institutions, including research centers, public enterprises, and government agencies, and population (Lee, 2009; Seo, 2009). The main focuses of the state intervention were to (1) mitigate over-concentration in few core regions, and (2) develop self-sufficient localization with regional economic competitiveness in periphery regions to reverse a self-reinforcing feedback structure (S. E. Kim, 2014; Seo, 2009).

The administration highlighted self-sustaining endogenous capabilities in regional development in periphery regions by developing 10 Innovation Cities with the relocation of 


\section{Mll Macrothink}

112 public institutions to reduce the centrality of the administrative and economic power. The administration intended to use the growth center-oriented approaches; that is, the Innovation Cities create innovation clusters in periphery regions with interactive cooperation between firms, educational institutions, and research centers. The clusters were expected to have a positive spillover effect on periphery regions (Seo, 2009).

Figure 2 shows the overview of 10 Innovation Cities. When planning the Innovation Cities, the national government considered innate characteristics in terms of regional economics and the long-term vision of each region. For instance, Ocean and Fisheries institutions relocated in Busan considering their geographic characteristic and regional industry. Also, institutions related to agriculture relocated to the Jeonbuk, where agriculture is a regional industrial foundation. Despite the consideration on the regional heterogeneity, the feature of the developmental state remained the regional policy, thereby eventually leading to the homogeneous top-down approach. In 2017, approximately 98 percent of public institutions moved, and the development project was completed.

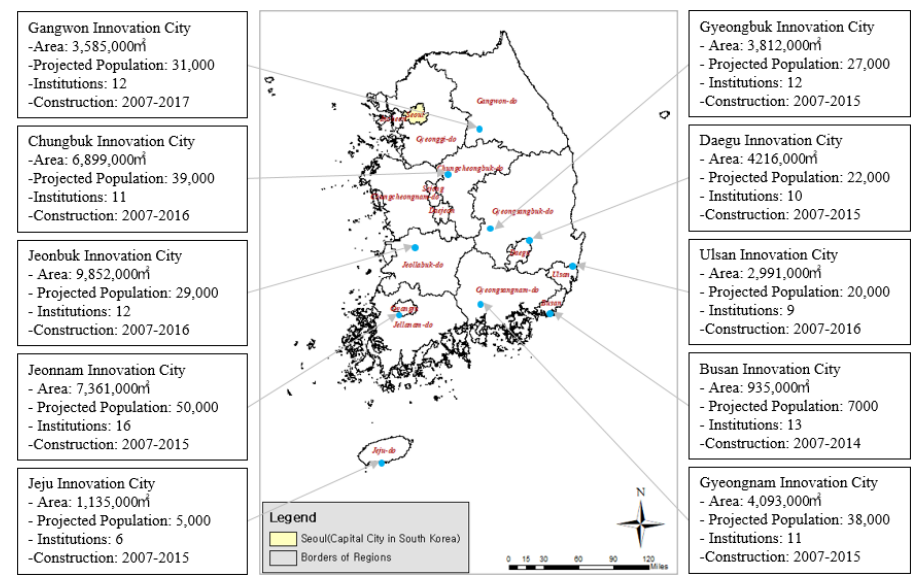

Figure 2. The Locations and Key Features of Innovation Cities

\section{Method}

\subsection{Research Question, Hypothesis, and Definitional Issue}

The central question for theoretical and empirical inquiry in this study is as follows.

$>$ Could the state intervention on decentralization be strong enough to reverse the tide of uneven development that has been intentionally created by the state?

Hypotheses made based on prior knowledge and common-sense intuition is as follows.

$>$ Only relocating the public institutions to periphery regions would not be effective to mitigate the regional uneven development that the developmental state has long created.

$>$ The relocation of public institutions would not be an effective way to attain the growth center-oriented approach by developing clusters between firms, universities, 
and research centers, thereby leading to insignificant positive spillover effect on regional economic competitiveness of periphery regions.

The question and hypothesis listed above bring up a research parameter that requires clarification on the vague concept of a region. In the theoretical perspective, the core-periphery dynamics need to be seen as nodal (polarized) regions resulting from internal flows, contacts, and interdependencies polarized towards a dominant center or node (Richardson, 1970). In this study, however, since regional policies in South Korea, implemented by the national government, have focused mainly on a capital city, provinces, and metropolitan cities (S. E. Kim, 2014), we define a region as the unity derives from political or administrative control. For the practical consideration of data collection and analysis, this study follows the administration system of South Korea. Therefore, we examine 16 regions, including one capital city, six metropolitan areas, and nine provinces (see Figure $1)$.

\subsection{Methodological Approach}

To answer the research question, this study attempts to quantify its effects on mitigating regional uneven development and analyze the changes in these effects at the regional level over time. We first employ the Ward Hierarchical Cluster Analysis of time-series with the Euclidean distance to pre-evaluate the number of clusters and makes a hierarchy of clusters using agglomerative or divisive algorithms. Then, we use the partitioning clustering (K-means Cluster Analysis) with the prespecified number of clusters. After defining the clusters for each index, we utilize a two-way analysis of variance (ANOVA) with the post-hoc comparison of the least square means to capture the mean difference between them.

\subsection{Data}

We use three indices, the Regional Creativity Potential Index, the Regional Innovation Index, and the Regional Development Index, developed by the Korea Institute for Industrial Economics and Trade (KIET). The indices are measured by diverse sectors with multiple indicators and relevant weights with the Analytic Hierarchy Process (AHP) (see Table 1). The indices also cover the long periods of time (before and after the development of the Innovation Cities). The advantages allow us to not only examine regional economic competitiveness comprehensively but also explore the effectiveness of the state intervention in a timely manner.

In details, the Regional Creativity Potential Index evaluates the degree of creativity of a region (J. Jang et al., 2014) . As shown in Table 1, it is composed of four categories of 3Ts (tolerance, talent, and technology) (Florida, 2003, 2005), and amenity. The Regional Innovation Index evaluates the relative level of innovation activities in the region based on the innovation system (J. Jang \& Yoo, 2017). The index is developed based on the European Innovation Scoreboard (EIS) methodology that reports the Summary Innovation Index (SII) and the Composite Innovation Index (CII) for each sector. The Regional Development Index is designed to comprehensively evaluate the development level of the region as well as the quality of life of the residents (Y. Kim \& Byeon, 2006). Given that Fledmand et al. (2016) 
define economic development as the expansion of economic capacities with a sustained increase in prosperity and quality of life, the analysis on the index that consider the two sectors, regional economy and quality of life, is essential because it can evaluate the degree of regional economic development. Further details on the three indices can be found in the Appendix.

The analysis period is between 2006 (before the development of Innovation Cities) and 2017 (after the development of Innovation Cities). The Regional Creativity Potential Index has a limited period from 2013 to 2017, while the other two indices are from 2006 to 2017. However, since creativeness is crucial to comprehend the regional economic competitiveness, we include the index in our research.

Table 1 The Framework to Develop the Three Indices (Source: the Korea Institute for Industrial Economic and Trade)

\begin{tabular}{|c|c|c|c|}
\hline Index & Sectors & $\begin{array}{l}\text { AHP } \\
\text { Weights }\end{array}$ & Description \\
\hline \multirow{4}{*}{$\begin{array}{l}\text { The Regional } \\
\text { Creativity } \\
\text { Potential } \\
\text { Index }\end{array}$} & Tolerance & 17.8 & $\begin{array}{l}\text { The tolerance is a sector to measure the diversity and openness } \\
\text { of the region and is composed of evaluation indicators such as } \\
\text { female and foreign workers. } \\
\text { While Florida uses the Gay index and the Bohemian index to } \\
\text { evaluate tolerance of a region, this sector adopts the indicators } \\
\text { related to women and foreigners as indicators due to the } \\
\text { cultural difference between the U.S. and South Korea. }\end{array}$ \\
\hline & Talent & 29.6 & $\begin{array}{l}\text { The talent is a sector to understand the ecosystem for fostering } \\
\text { employees and talents in high value-added industries, and is } \\
\text { composed of evaluation indicators, such as education } \\
\text { infrastructure, and knowledge-based industries. This sector is } \\
\text { composed of indicators such as education infrastructure and } \\
\text { employment in knowledge-based industries. }\end{array}$ \\
\hline & Technology & 32.5 & $\begin{array}{l}\text { The technology is a sector to identify R\&D and high-tech } \\
\text { businesses and consists of evaluation indicators of R\&D } \\
\text { investments, institutions, and knowledge-based industry } \\
\text { businesses. This sector includes indicators of R\&D personnel, } \\
\text { investments, institutions, and knowledge-based industry } \\
\text { businesses to identify R\&D and high-tech industries. }\end{array}$ \\
\hline & Amenity & 20.1 & $\begin{array}{l}\text { The amenity is a sector to understand the settlement conditions } \\
\text { related to the quality of life and comprises evaluation indexes } \\
\text { such as culture, social services, and medical care. }\end{array}$ \\
\hline \multirow{2}{*}{$\begin{array}{l}\text { The Regional } \\
\text { Innovation } \\
\text { Index }\end{array}$} & $\begin{array}{l}\text { Innovation } \\
\text { Input }\end{array}$ & N.A. & $\begin{array}{l}\text { The innovation input is a sector to identify each region's } \\
\text { innovation potential that considers human capital and } \\
\text { investment in knowledge creation activities. }\end{array}$ \\
\hline & $\begin{array}{l}\text { Innovation } \\
\text { Output }\end{array}$ & N.A. & $\begin{array}{l}\text { The innovation output is a sector to measure the innovative } \\
\text { sector's economic performance that considers the usage of } \\
\text { innovative knowledge and patent activities. }\end{array}$ \\
\hline $\begin{array}{l}\text { The Regional } \\
\text { Development } \\
\text { Index }\end{array}$ & $\begin{array}{l}\text { Quality of } \\
\text { life }\end{array}$ & 72.6 & $\begin{array}{l}\text { The regional economy is a sector to evaluate the economic } \\
\text { power of the region. It comprises five evaluation indicators } \\
\text { representing each region's economic capacity, including } \\
\text { income, level, innovation capacity, human resource base, } \\
\text { industrial development, SOC, and financial budgetary abilities. } \\
\text { The quality of life is a sector to identify the living conditions of } \\
\text { residents in the region and consists of five evaluation indicators } \\
\text { representing the living conditions of each resident, such as } \\
\text { residential, working, educational, cultural, and environmental } \\
\text { conditions. }\end{array}$ \\
\hline
\end{tabular}




\section{Results}

\subsection{The Regional Creativity Potential Index}

By performing Ward hierarchical and K-means cluster analysis, three clusters are identified. The dendrogram indicates that there are two core regions (Seoul and Daejeon), three semi-core regions (Gyeonggi, Chungnam, \& Gwangju), and eleven periphery regions (see Figure 3). In this analysis, Seoul and Daejeon are the most competitive region in terms of creativeness potential between 2013 and 2017 (see Figure 6). Seoul is a capital city and the largest metropolis of South Korea, meaning highly concentrated human capital, high-technology industries, institutions, and amenities (J.-H. Jang, 2009). Our finding is consistent with the previous literature. Kwon et al. (2012) explores the urban competitiveness index that factors in the formation of the cluster, human capital, and creative economy, and finds that except for Seoul, Daejeon leads in almost all factors.

We use a two-way analysis of variance (ANOVA) with the Post-hoc comparison of least square means to determine if the categorization of regions and periods affects the average figures of the index. The result is presented in Table 2; overall, it supports our hypothesis. Given the p-value of less than 0.001, the average figures of the core regions (0.581), semi-core regions $(0.360)$, and periphery regions $(0.254)$ are significantly different, though the interaction between the two terms is not significant. The mean difference between periods finds insignificant $(\mathrm{p}=0.840)$. Despite the insignificant differences, there is a meaningful relative increase in Jeju's index from 2013 (0.24) to 2017 (0.29). Specifically, the measurement of tolerance among the four sectors in the region increased by $70 \%$.

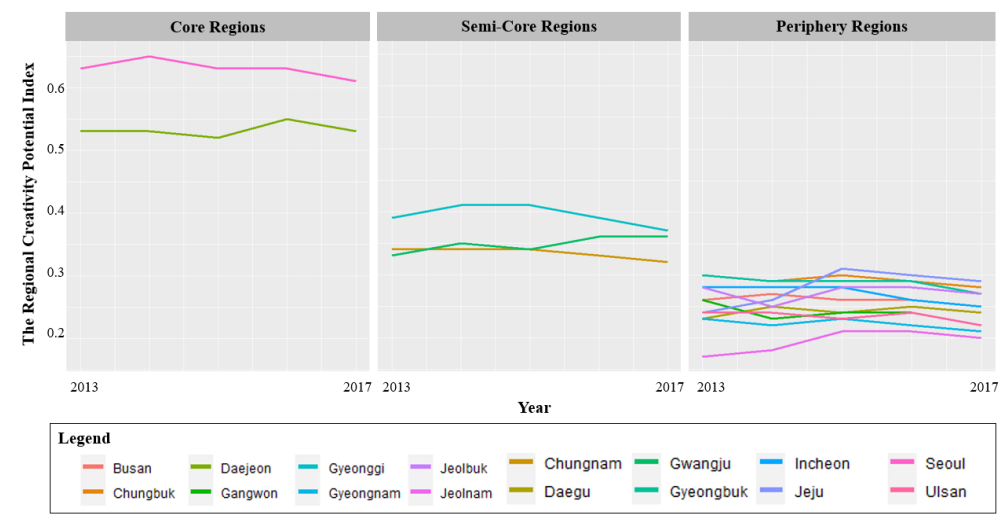

Figure 3. The Trends in the Regional Creativity Potential Index of the Three Clusters over Time

\subsection{The Regional Innovation Index}

The results of the cluster analysis on the Regional Innovation Index show that there are three core regions (Seoul, Daejeon, and Gyeonggi), four semi-core regions (Chungnam, Chungbuk, Gyeongbuk, and Incheon), and nine periphery regions (see Figure 4). Given Seoul's centrality in the Korean economy and the enormous attraction it has for talented Koreans from around the nation (Sohn \& Kenney, 2007), it is not surprising that the region has the highest innovation inputs, such as the most high-technology startups, and innovation outputs, such as 
the number of patent.

As we expected, the mean difference in the Regional Innovation Index between three regional groups is significant, suggesting that the core regions have had the highest number of innovation inputs and outputs than semi-core and periphery regions. The post-hoc test reveals significant pairwise differences between core regions (0.607), semi-core regions (0.371), and periphery regions $(0.187)$. The results further indicate that the classification of the regions into three regions has not changed before and after the development of Innovation Cities (see Figure 4). Regarding the relative change in the index between 2006 and 2017, the index of Seoul relatively decreased. The research institutions that moved from Seoul to Innovation Cities in periphery regions may explain the results.

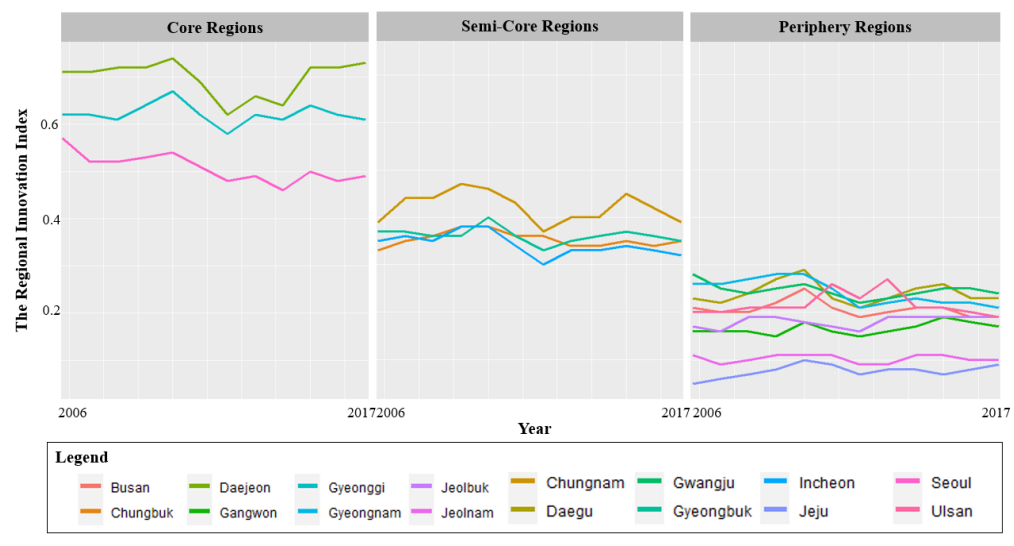

Figure 4. The Trends in the Regional Innovation Index of the Three Clusters over Time

\subsection{The Regional Development Index}

Regarding the Regional Development Index, the cluster analysis reveals that there are four core regions (Seoul, Daejeon, Gyeonggi, and Ulsan), nine semi-core regions (Chungnam, Chungbuk, Gyeongnam, Gyeongbuk, Jeju, Incheon, Busan, Daegu, and Gwangju), and three periphery regions (see Figure 5). The three regions, which are Jeolnam, Julbuk, and Gangwon, are identified as periphery regions in all three indices. Since 1997, the concentration of manufacturing growth in Gyeonggi has been considerable due to the locational advantage adjacent to Seoul. Moreover, the province takes advantage of industrial transformation toward technologically intensive industries and research (Seo, 2009) and government policy, such as a significant amount of new town development for decades. Ulsan is identified as a core region largely due to a high level of industrial (manufacturing) concentration, such as Hyundai, which, in turn, leads to the regional economic growth, while the region is identified the periphery in terms of creativity and innovation. Surprisingly, Busan's index, the second largest city of South Korea, where export industries are concentrated since 1960s has been lower than the four core regions for the two decades. We think that diverse factors, including the relocation of labor-intensive industries to Southeast Asia (Bae, 2003), may explain this result.

In Table 2, a notable finding of our model regards mean differences between clusters and periods; that is, while the insignificant mean difference is found in the interaction term, there 
is a significant mean difference between the three regional groups $(p<0.001)$. Interestingly, the core regions showed the highest regional economy figure, while the average quality of life measurement of the regional group was the lowest.

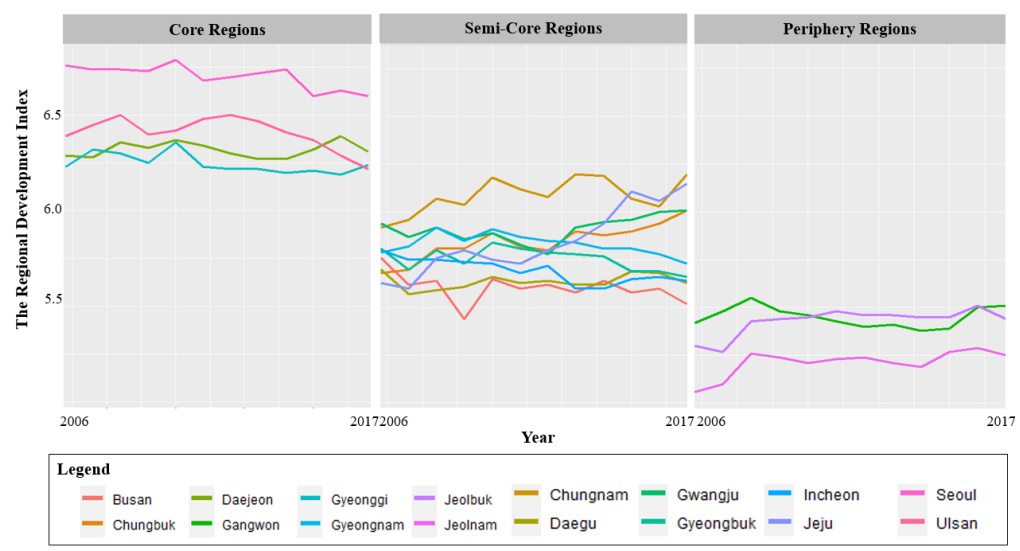

Figure 5. The Trends in the Regional Development Index of the Three Clusters over Time

Table 2. The Results of Two-Way Analysis of Variance (ANOVA) with Cluster Analysis of Time-Series (Data Source: the Korea Institute for Industrial Economics and Trade)

\begin{tabular}{|c|c|c|c|c|c|c|}
\hline & \multicolumn{3}{|c|}{ Least square means } & \multicolumn{3}{|c|}{ P-value of ANOVA } \\
\hline & $\begin{array}{l}\text { Core } \\
\text { regions }\end{array}$ & $\begin{array}{l}\text { Semi-core } \\
\text { regions }\end{array}$ & $\begin{array}{l}\text { Periphery } \\
\text { regions }\end{array}$ & $\begin{array}{l}\text { Main effects } \\
\text { for cluster }\end{array}$ & $\begin{array}{l}\text { Main effects } \\
\text { for periods }\end{array}$ & $\begin{array}{l}\text { Inter-action } \\
\text { effect }\end{array}$ \\
\hline \multicolumn{7}{|c|}{ The Regional Creativity Potential Index (time-period: 2013 2017) } \\
\hline Overall & 0.581 & 0.360 & 0.254 & $<0.001$ & 0.692 & 0.996 \\
\hline Tolerance & 0.101 & 0.065 & 0.057 & 0.006 & 0.925 & 0.998 \\
\hline Talent & 0.170 & 0.118 & 0.076 & $<0.001$ & 0.950 & 0.999 \\
\hline Technology & 0.208 & 0.128 & 0.076 & $<0.001$ & 0.810 & 0.999 \\
\hline Amenity & 0.100 & 0.052 & 0.045 & $<0.001$ & 0.999 & 0.999 \\
\hline \multicolumn{7}{|c|}{ The Regional Innovation Index (time-period: 2006 2017) } \\
\hline Overall & 0.607 & 0.371 & 0.187 & $<0.001$ & 0.685 & 0.999 \\
\hline Input & 0.623 & 0.337 & 0.159 & $<0.001$ & 0.999 & 0.999 \\
\hline Output & 0.594 & 0.405 & 0.217 & $<0.001$ & 0.516 & 0.999 \\
\hline \multicolumn{7}{|c|}{ The Regional Development Index (time-period: 2006 2017) } \\
\hline Overall & 6.42 & 5.80 & 5.37 & $<0.001$ & 0.992 & 0.999 \\
\hline Regional Economy & 6.53 & 5.66 & 4.99 & $<0.001$ & 0.999 & 0.999 \\
\hline Quality of Life & 6.13 & 6.18 & 6.36 & 0.038 & 0.844 & 0.999 \\
\hline
\end{tabular}

\section{Discussion and Conclusion}

"Economists have long recognized the existence and stubborn persistence of regional dualism at all levels of national development and throughout the historical experience of almost all presently developed countries" (Williamson, 1965, p. 3). The issue of regional uneven development in South Korea has attracted considerable political and economic attention, as it has been struggling with the deliberately created uneven development with the developmental state. South Korea was dedicated to mitigating deliberately-formed regional polarization with the state intervention to reverse the perpetual spatial disparity (Seo, 2009). However, the government-led efforts for decades were not effective. Thus, Roh Mu-Hyun administration in 2003 developed a policy framework, Innovation Cities, to achieve balanced regional 
economic development via the decentralization of administration power and public institutions. The administration intended to use the growth center-oriented approaches; that is, the Innovation Cities create innovation clusters in periphery regions with interactive cooperation between firms, educational institutions, and research centers. The clusters were also expected to have a positive spillover effect on periphery regions.

This paper analyzes the effectiveness of governmental-led large scale new town development project, Innovation Cities. We use a two-way analysis of variance (ANOVA) with the Ward Hierarchical Cluster Analysis by using well-defined three indices (the Regional Creativity Potential Index, the Regional Innovation Index, and the Regional Development Index) on regional economic competitiveness. There has been a debate on the effectiveness of Innovation Cities in mitigating uneven development practices in South Korea. Some contend that there have been positive spillover effects of the relocation of public institutions, such as purchasing local products for institutional events and hiring students who graduate from educational institutions in the periphery region (Joo, 2020).

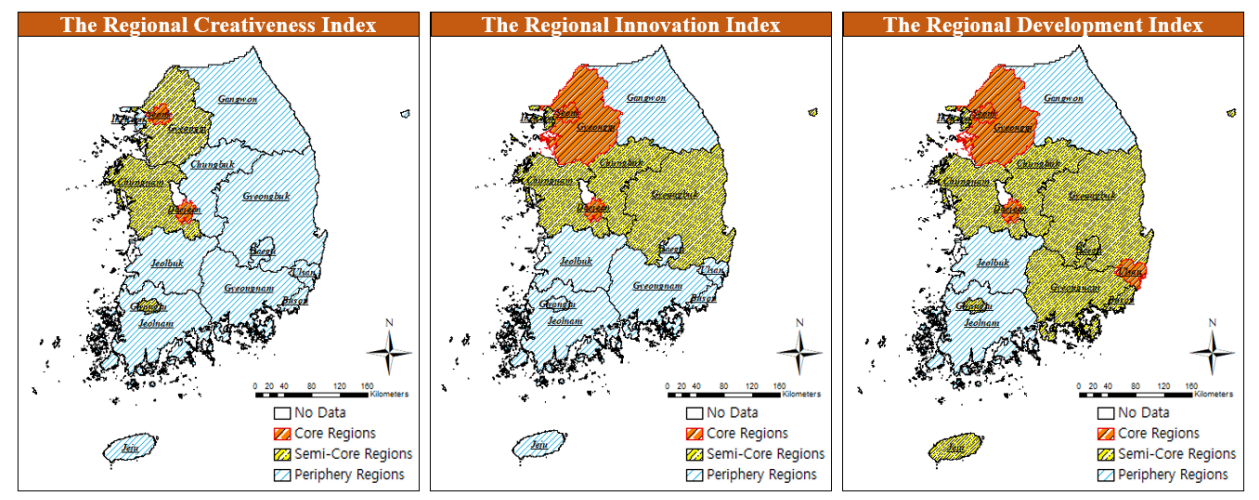

Figure 6. Classification of Core, Semi-Core, and Periphery Regions based on the Ward

Hierarchical Cluster Analysis for each Indices regarding Regional Competitiveness

However, we find that the state intervention does not have a significant impact on reversing the negative path dependence of periphery regions. At best, the results show that the regional disparity has not widened; however, it does not necessarily mean that the decentralization effort has a noticeable effect on reducing the regional gap between three regional groups in Figure 6. Importantly, we do not find a statistically significant difference in the average figure of the indices between different periods, suggesting that the regional competitiveness has not changed before and after the development of Innovation Cities. The results also imply that the trickle-down effects that neoliberalism contends have not been observed during the time-period.

Based on the results, we have policy implications. Policymakers carefully consider diverse full-factors toward periphery regions with consideration of the regional heterogeneity rather than focusing on the homogeneous approach. For the regional economic development in periphery regions, they need to focus on not only production-side and but also consumption-side viewpoints. Glaeser et al. (2001) contend that diverse amenities in cities, such as various services and consumer goods, and aesthetic and environmental settings, can 
attract people and firms from the consumption-side standpoint. This suggests that without the relocation of the amenities to periphery regions, individuals and firms would not move from the core-region. Second, in periphery regions where the basic sector is not a dominant industry, local consumption activities can be a source of long-term regional economic development and stability. The consumption base theory argues that superior locally produced goods and services would bring better human capital, firms, and retirement incomes into a region, leading to diversity and economic growth (Markusen \& Schrock, 2009). That is, in the regions without a strong export base industry, public policies also need to focus on local consumption base to reverse the regional path dependence.

There are some limitations in this research. For instance, since the unit of analysis is large, our study does not capture a detailed picture at the finer level of geographies. Moreover, the methodological approach of this paper can be deemed as a simple comparative analysis of trend data. Lastly, this research may be premature to examine the effectiveness of the development of Innovation Cities on increasing regional economic competitiveness in periphery regions because the construction of the cities was mostly in 2017.

\section{References}

Ahn, G., Park, Y., Park, H., \& Shim, G. (2003). A research on the goal setting and indicator development for balanced regional development. Seoul University.

Amin, A. (1999). An Institutionalist Perspective on Regional Economic Development (Vol. 14).

Amsden, A. H. (1992). Asia's Next Giant: South Korea and Late Industrialization (Revised edition). Oxford University Press.

Bae, K. W. (2003). The Evolution of Regional Economic Disparities in Korea. KOREA JOURNAL, 26.

Barzotto, M., Corradini, C., Fai, F. M., Labory, S., \& Tomlinson, P. R. (2019). Enhancing innovative capabilities in lagging regions: An extra-regional collaborative approach to RIS3. Cambridge Journal of Regions, Economy and Society, 12(2), 213-232. https://doi.org/10.1093/cjres/rsz003

Camagni, R. P. (1995). The Concept of Innovative Milieu and Its Relevance for Public Policies in European Lagging Regions. Papers in Regional Science, 74(4), 317-340. https://doi.org/10.1111/j.1435-5597.1995.tb00644.x

Choi, B. D. (2007). Beyond Developmentalism and Neoliberalism: Development Process and Alternative Visions for Korean Geography. Journal of the Korean Geographical Society, $42(2), 218-242$.

Cojanu, V. (2008). Theorising Uneven Development: The Epistemic Value of History and Complexity in the Study of Economic Evolutions. Trames. Journal of the Humanities and Social Sciences, 12(4), 450. https://doi.org/10.3176/tr.2008.4.06

Fan, C. C., \& Casetti, E. (1994). The spatial and temporal dynamics of US regional income inequality, 1950-1989. The Annals of Regional Science, 28(2), 177-196. https://doi.org/10.1007/BF01581768 
Feldman, M., Hadjimichael, T., Lanahan, L., \& Kemeny, T. (2016). The logic of economic development: A definition and model for investment. Environment and Planning C: Government and Policy, 34(1), 5-21. https://doi.org/10.1177/0263774X15614653

Florida, R. (2003). Cities and the Creative Class. City \& Community, 2(1), 3-19. https://doi.org/10.1111/1540-6040.00034

Florida, R. (2005). Cities and the Creative Class (1st Edition). Routledge.

Frenkel, A. (2000). Can regional policy affect firms' innovation potential in lagging regions? The Annals of Regional Science, 27.

Friedmann, J. (1969). The Role of Cities in National Development. American Behavioral Scientist, 12(5), 13-21. https://doi.org/10.1177/000276426901200503

Friedmann, J., \& Weaver, C. (1979). Polarized Development. In Territory and Function: The Evolution of Regional Planning Doctrine (pp. 114-139). University of California Press.

Glaeser, E. L., Kolko, J., \& Saiz, A. (2001). Consumer city. Journal of Economic Geography, 1(1), 27-50. https://doi.org/10.1093/jeg/1.1.27

Halvorson, D. (2016). States of Disorder: Understanding State Failure and Intervention in the Periphery. Routledge.

Hirschman, A. O. (1958). The Strategy of Economic Development. Yale University Press.

Isaksen, A., \& Trippl, M. (2017). Exogenously Led and Policy-Supported New Path Development in Peripheral Regions: Analytical and Synthetic Routes. Economic Geography, 93(5), 436-457. https://doi.org/10.1080/00130095.2016.1154443

Jang, J., \& Yoo, Y. (2017). The Analysis of Regional Innovation Activity and Policy Effect. The Korea Institute for Industrial Economic and Trade.

Jang, J., Song, H., Kim, H., Heo, M., Kim, C., \& Byeon, C. (2014). The Analysis of spatial distribution and accumulation factors in creative industries. The Korea Institute for Industrial Economic and Trade.

Jang, J.-H. (2009). Regional Development Policy in Korea-Past, Present, and Future. The Economic Geographical Society of Korea, 12(4), 576-596. https://doi.org/10.23841/EGSK.2009.12.4.576

Joo, J. (2020). Relocation of public institutions to Innovation Cities, it is too early to say failure. The Kyunghyang Shinmun. Retrieved from https://m.khan.co.kr/view.html?art_id=202009261535001

Kim, S. E. (2014). Regional Policy and National Development in Korea. The Korean Journal of Policy Studies, 29(1), 101-122.

Kim, S. T., Jung, C. S., \& Roh, K. H. (1991). Regional Economic Gap in Korea. Journal of Economic Development, 16(2), 145-167.

Kim, Y., \& Byeon, C. (2006). The Development of Regional Development Index and Analysis of Regional Development Gap. The Korea Institute for Industrial Economic and Trade.

Krugman, P. (1992). Center and Periphery. In Geography and Trade (pp. 1-34). The MIT Press.

Krugman, P. (1999). The Role of Geography in Development. International Regional Science Review, 22(2), 142-161. https://doi.org/10.1177/016001799761012307 
Kwon, S., Kim, J., \& Oh, D.-S. (2012). Measurement of Urban Competitiveness Based on Innovation Indicators in Six Metropolitan Cities in Korea. World Technopolis Review, 1(3), 177-185. https://doi.org/10.7165/wtr2012.1.3.177

Lee, Y. S. (2009). Balanced Development in Globalizing Regional Development? Unpacking the New Regional Policy of South Korea. Regional Studies, 43(3), 353-367. https://doi.org/10.1080/00343400802171981

Markusen, A., \& Schrock, G. (2009). Consumption-Driven Urban Development. Urban Geography, 30(4), 344-367. https://doi.org/10.2747/0272-3638.30.4.344

Martin, P. (1998). Can Regional Policies Affect Growth and Geography in Europe? The World Economy, 21(6), 757-774. https://doi.org/10.1111/1467-9701.00162

Martin, R., \& Sunley, P. (2006). Path dependence and regional economic evolution. Journal of Economic Geography, 6(4), 395-437. https://doi.org/10.1093/jeg/lb1012

Meardon, S. J. (2001). Modeling Agglomeration and Dispersion in City and Country: Gunnar Myrdal, François Perroux, and the New Economic Geography. American Journal of Economics and Sociology, 60(1), 25-57. https://doi.org/10.1111/1536-7150.00053

Minns, J. (2001). Of miracles and models: The rise and decline of the developmental state in South Korea. Third World Quarterly, 22(6), 1025-1043. https://doi.org/10.1080/01436590120099777

Myrdal, G. (1957). The Principle of Circular and Cumulative Causation. In Economic Theory and Under-Developed Regions (pp. 11-38). HARPER \& BROTHERS PUBLISHING; Volume 16 of World Perspectives edition.

Nemethova, V., Siranova, M., \& Sipikal, M. (2019). Public support for firms in lagging regions-Evaluation of innovation subsidy in Slovakia. Science and Public Policy, 46(2), 173-183. https://doi.org/10.1093/scipol/scy046

North, D. C. (1955). Location Theory and Regional Economic Growth. Journal of Political Economy, 63(3), 243-258.

Onis, Z., Amsden, A. H., Deyo, F. C., Johnson, C., \& Wade, R. (1991). The Logic of the Developmental State. Comparative Politics, 24(1), 109. https://doi.org/10.2307/422204

Park, B.-G. (2008). Uneven Development, Inter-scalar Tensions, and the Politics of Decentralization in South Korea: The politics of decentralization in South Korea. International Journal of Urban and Regional Research, 32(1), 40-59. https://doi.org/10.1111/j.1468-2427.2008.00765.x

Perroux, F. (1950a). The Domination Effect and Modern Economic Theory. Social Research, 17(2), 188-206. JSTOR.

Perroux, F. (1950b). Economic Space: Theory and Applications. The Quarterly Journal of Economics, 64(1), 89-104. https://doi.org/10.2307/1881960

Radice, H. (2008). The Developmental State under Global Neoliberalism. Third World Quarterly, 29(6), 1153-1174. https://doi.org/10.1080/01436590802201121

Richardson, H. W. (1970). Introduction (pp. 17-37). Palgrave Macmillan.

Rodríguez-Pose, A. (2001). Is R\&D investment in lagging areas of Europe worthwhile? Theory and empirical evidence*. Papers in Regional Science, 80(3), 275-295. 


\section{Macrothink}

International Journal of Regional Development

ISSN 2373-9851 2021, Vol. 8, No. 2

https://doi.org/10.1111/j.1435-5597.2001.tb01800.x

Rubara, E. (2014). Uneven development: Understanding the roots of inequality. Pambazuka News: Voices for Freedom and Justice. https://www.pambazuka.org/governance/uneven-development-understanding-roots-inequality Seo, J. K. (2009). Balanced national development strategies: The construction of Innovation Cities in Korea. Land Use Policy, 26(3), 649-661. https://doi.org/10.1016/j.landusepol.2008.08.014

Smith, N. (2010). Uneven Development: Nature, Capital, and the Production of Space. University of Georgia Press.

Sohn, D.-W., \& Kenney, M. (2007). Universities, Clusters, and Innovation Systems: The Case of Seoul, Korea. World Development, 35(6), 991-1004. https://doi.org/10.1016/j.worlddev.2006.05.008

Swyngedouw, E., \& Heynen, N. C. (2003). Urban Political Ecology, Justice and the Politics of Scale. Antipode, 35(5), 898-918. https://doi.org/10.1111/j.1467-8330.2003.00364.x

Tiebout, C. M. (1956). A Pure Theory of Local Expenditures. The Journal of Political Economy, 64(5), 416-424.

Tondl, G. (1998). EU Regional Policy in the Southern Periphery: Lessons for the Future. South European Society and Politics, 3(1), 93-129. https://doi.org/10.1080/13608740308539527

Wei, Y. D. (2002). Multiscale and Multimechanisms of Regional Inequality in China: Implications for regional policy. Journal of Contemporary China, 11(30), 109-124. https://doi.org/10.1080/10670560120091165

Williamson, J. G. (1965). Regional Inequality and the Process of National Development: A Description of the Patterns. Economic Development and Cultural Change, 13(4, Part 2), 1-84. https://doi.org/10.1086/450136

Zheng, S., \& Kahn, M. E. (2013). China's bullet trains facilitate market integration and mitigate the cost of megacity growth. Proceedings of the National Academy of Sciences, 110(14), E1248-E1253. https://doi.org/10.1073/pnas.1209247110 
Appendix

Table 3. The Detailed Framework to Develop the Regional Creativity Potential Index (Source: J. Jang et al., 2014)

\begin{tabular}{|c|c|c|c|}
\hline Sectors & $\begin{array}{l}\text { AHP } \\
\text { Weights }\end{array}$ & Indicators & $\begin{array}{l}\text { AHP } \\
\text { Weights }\end{array}$ \\
\hline \multirow{4}{*}{ Tolerance } & \multirow{4}{*}{17.8} & The ratio of female population aged 21-30 to the total population & 1.0 \\
\hline & & The female economic activity participation rate & 1.0 \\
\hline & & The proportion of foreign professionals to total employment & 1.0 \\
\hline & & The ratio of foreign women to the total population & 1.0 \\
\hline \multirow{9}{*}{ Talent } & \multirow{9}{*}{29.6} & The ratio of the population with college graduates or higher to total employment & 1.0 \\
\hline & & The number of colleges and universities per population & 1.0 \\
\hline & & The number of private academies per person & 1.0 \\
\hline & & The number of college and university faculty per person & 1.0 \\
\hline & & The number of colleges and universities per area & 1.0 \\
\hline & & The number of private academies per area & 1.0 \\
\hline & & The number of college and university faculty per area & 1.0 \\
\hline & & The share of employment in the knowledge-based manufacturing industry to total employment & 1.0 \\
\hline & & The share of employed in the knowledge-based service industry to total employment & 1.0 \\
\hline \multirow{8}{*}{ Tech-nology } & \multirow{8}{*}{32.5} & The number of patents per person & 1.0 \\
\hline & & The number of patents per R\&D workforce & 1.0 \\
\hline & & The number of R\&D personnel per person & 1.0 \\
\hline & & The number of $R \& D$ institutions per person & 1.0 \\
\hline & & The R\&D investment per person & 1.0 \\
\hline & & The number of $R \& D$ personnel per $R \& D$ institution & 1.0 \\
\hline & & The share of knowledge-based manufacturing businesses relative to total companies & 1.0 \\
\hline & & The share of knowledge-based service businesses relative to total companies & 1.0 \\
\hline \multirow{10}{*}{ Amenity } & \multirow{10}{*}{20.1} & The number of cultural facilities per person & 1.0 \\
\hline & & The number of social welfare facilities per person & 1.0 \\
\hline & & The number of childcare facilities per infant & 1.0 \\
\hline & & The number of hospital beds per person & 1.0 \\
\hline & & The number of doctors per person & 1.0 \\
\hline & & The number of cultural facilities per area & 1.0 \\
\hline & & The number of social welfare facilities per area & 1.0 \\
\hline & & The number of childcare facilities per area & 1.0 \\
\hline & & The number of hospital beds per area & 1.0 \\
\hline & & The number of doctors per area & 1.0 \\
\hline
\end{tabular}




\section{Macrothink}

International Journal of Regional Development

ISSN 2373-9851

2021, Vol. 8, No. 2

Table 4. The Detailed Framework to Develop the Regional Innovation Index (Source: J. Jang \& Yoo, 2017)

\begin{tabular}{|c|c|c|c|}
\hline Sectors & Sub-Sectors & Indicators & $\begin{array}{l}\text { AHP } \\
\text { Weights }\end{array}$ \\
\hline \multirow{9}{*}{$\begin{array}{l}\text { Innovation } \\
\text { input }\end{array}$} & \multirow{4}{*}{ Human capital } & The ratio of R\&D personnel in the public sector to the total number of employees & 1.0 \\
\hline & & The ratio of $R \& D$ personnel in the private sector to the total number of employees & 1.0 \\
\hline & & $\begin{array}{l}\text { The ratio of workers in the knowledge-based manufacturing industry to workers in the } \\
\text { manufacturing industry }\end{array}$ & 1.0 \\
\hline & & The ratio of knowledge-based service workers to workers in the service industry & 1.0 \\
\hline & \multirow{4}{*}{ Knowledge creation } & The share of R\&D expenditure in the public sector to GRDP & 1.0 \\
\hline & & The share of R\&D expenditure in the private sector to GRDP & 1.0 \\
\hline & & The number of R\&D organizations in the public sector per a thousand units of businesses & 1.0 \\
\hline & & The Number of R\&D organizations in the private sector per a thousand units of businesses & 1.0 \\
\hline & \multirow{4}{*}{$\begin{array}{l}\text { The usage } \\
\text { knowledge }\end{array}$} & The number of businesses ventures per a thousand units of businesses & 1.0 \\
\hline \multirow{6}{*}{$\begin{array}{l}\text { Innovation } \\
\text { output }\end{array}$} & & $\begin{array}{l}\text { The share of added value in high-tech industries among the total added value of the } \\
\text { manufacturing industry }\end{array}$ & 1.0 \\
\hline & & The share of exports of high-tech products among the total exports & 1.0 \\
\hline & & $\begin{array}{l}\text { The share of the number of workers in industries that require higher-intermediate } \\
\text { technology among the total number of workers in the manufacturing industry }\end{array}$ & 1.0 \\
\hline & \multirow{3}{*}{$\begin{array}{l}\text { Intellectual property } \\
\text { rights }\end{array}$} & The number of patent and utility model applications per million population & 2.0 \\
\hline & & The number of design applications per million population & 1.0 \\
\hline & & The number of trademark applications per million population & 1.0 \\
\hline
\end{tabular}


Table 5. The Detailed Framework to Develop the Regional Development Index (Source: Y. Kim \& Byeon, 2006)

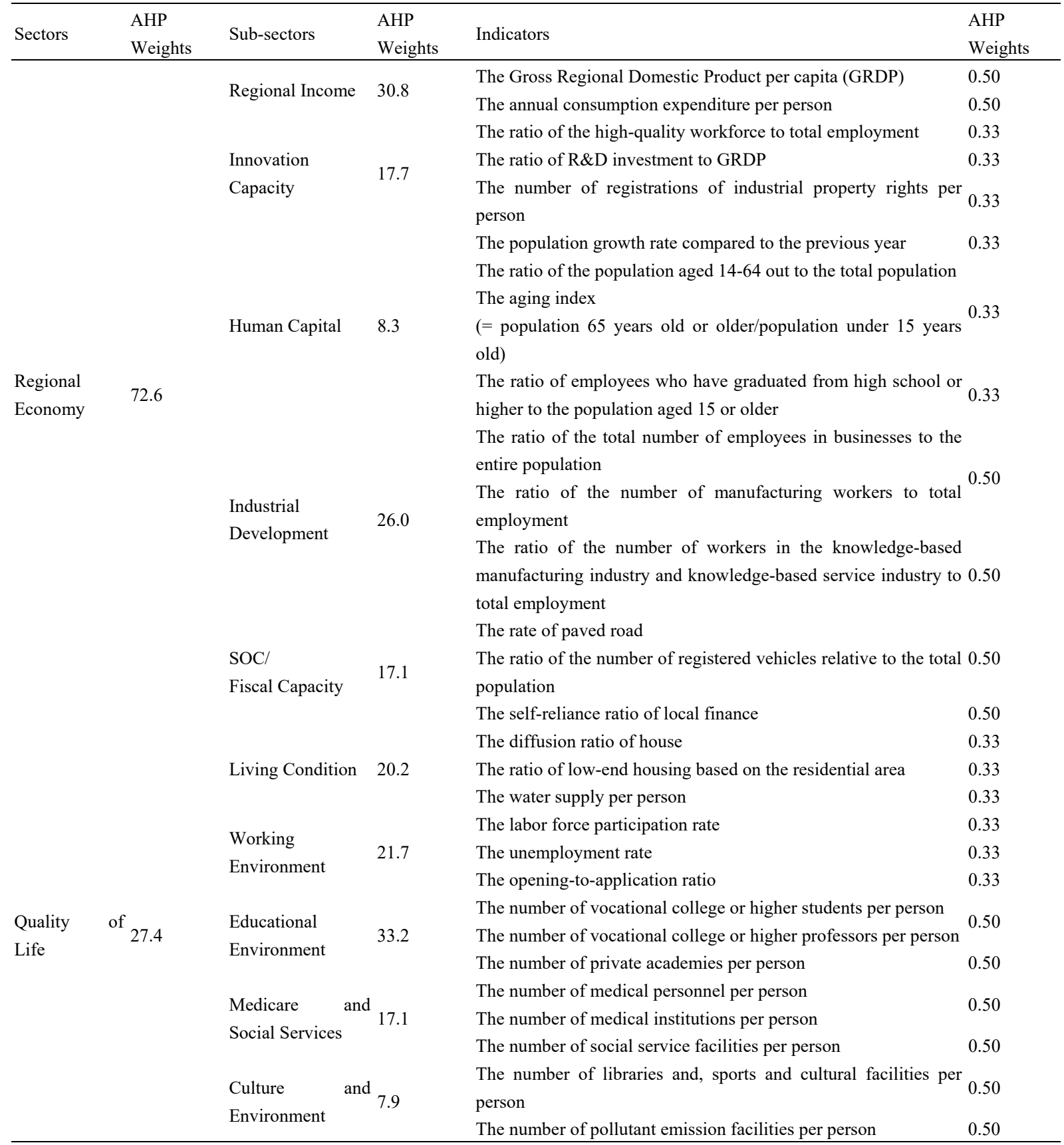

\section{Copyrights}

Copyright for this article is retained by the author(s), with first publication rights granted to the journal.

This is an open-access article distributed under the terms and conditions of the Creative Commons Attribution license (http://creativecommons.org/licenses/by/4.0/) 